\title{
Risk of Insolvency and Return of Shares: Empirical Analysis of Altman's Z-Score in the Peruvian Mining Sector between 2008 and 2018*
}

Edmundo R. Lizarzaburu**

Kurt Burneo***

Luis Berggrun ${ }^{\star \star \star \star}$

Received date: 2019, December 11

Approved date: 2020, July 12

To cite this article: Lizarzaburu, E. R., Burneo, K., \& Berggrun, L. (2021). Risk of Insolvency and Return of Shares: Empirical Analysis of Altman's Z-Score in the Peruvian Mining Sector between 2008 and 2018. Revista Universidad E Empresa, 23(40), 1-33. https://doi.org/10.12804/revistas.urosario.edu.co/empresa/a.8558

\section{Abstract}

This research pretends to evaluate the significance of the insolvency risk, referred by Altman's Z-Score, in the explanation of the historical return of the seven most liquid mining companies listed in the Lima Stock Exchange (BVL) based on a Market Return Model (MRM) under a cross-sectional approach. In this sense, daily data was collected from the s\&p/BvL Peru Select index and the Peruvian 10-year Sovereign Bond between 2008 and 2018, approximated quarterly by the geometric average to homogenize them with

\footnotetext{
* The document had the collaboration of Diego Ezquivel.

** PhD. Professor at Universidad Esan (Perú). Email: elizarzaburub@gmail.com

*** PhD. Centrum Católica Graduate Business School (ccGBs)/Pontificia Universidad Católica del Perú. Email: kburneo@pucp. edu.pe
} 
the frequency of the Z. Thus, two central results were obtained: (1) The Z-Score, as an estimator of insolvency risk, is not valid to explain the behavior of the historical return of the shares, and (2) The Market Premium is statistically significant within the yield analysis. Additionally, contrary to the common literature, the results suggest the validity of Sharpe's conventional CAPM.

Keywords: Financial distress; insolvency risk; Z-Score; historical stock performance; emerging markets; mining sector.

\section{Riesgo de insolvencia y devolución de acciones: análisis empírico de la puntuación Z de Altman en el sector minero peruano entre 2008 y 2018}

\section{Resumen}

Esta investigación pretendía evaluar la importancia del riesgo de insolvencia, referido por la puntuación Z de Altman, en la explicación del rendimiento histórico de las siete empresas mineras más líquidas que cotizan en la Bolsa de Valores de Lima (BvL) con base en un modelo de retorno de mercado bajo un enfoque transversal. En este sentido, se recolectaron datos diarios del índice s\&p/BvL Peru Select y del Bono Soberano Peruano a diez años entre 2008 y 2018, aproximados trimestralmente por el promedio geométrico para homogeneizarlos con la frecuencia de Z. Así, se obtuvieron dos resultados centrales: (1) el Z-Score, como estimador de riesgo de insolvencia, que no es válido para explicar el comportamiento de la rentabilidad histórica de las acciones, y (2) la prima de mercado, que es estadísticamente significativa dentro del análisis de rentabilidad. Además, contrariamente a la literatura común, los resultados sugieren la validez del capm convencional de Sharpe.

Palabras clave: problemas financieros; riesgo de insolvencia; puntuación $Z$; rendimiento histórico de las acciones; mercados emergentes; sector minero.

\section{Risco de inadimplência e devolução de ações: análise empírica da pontuação Z de Altman no setor mineiro peruano entre 2008-2018}

\section{Resumo}

Esta pesquisa pretende avaliar a importância do risco de inadimplência, calculado pela pontuação Z de Altman, na explicação de rendimento histórico das 7 empresas mineiras mais proeminentes na bolsa de valores de Lima, com base em um Modelo de Retorno de Mercado sobre um enfoque transversal. Neste sentido, coletaram-se dados diários do indicador s\&p/Bvt Peru Select e do Bônus Soberano Peruano no período de 10 anos entre 20082018, calculados trimestralmente pela média geométrica para homogeneizá-los com a frequência Z. Dessa forma, obteve-se como resultados centrais: (1) o score Z, como estimativa de risco de inadimplência, que não é válido para explicar o comportamento de rentabilidade histórica das ações, e (2) a taxa de mercado, que é estatisticamente significativa dentro da análise de rentabilidade. Adicionalmente, contrário ao descrito na literatura, os resultados sugerem a validade do CAPM convencional de Sharpe.

Palavras-chave: problemas financeiros; risco de inadimplência; pontuação Z; rendimento histórico das ações; mercados emergentes; setor mineiro. 


\section{Introduction}

At present, it is common to find in the literature the indiscriminate use of the concepts financial stress and insolvency, which represent two different situations an entity could cross, correlated through a unidirectional attainment link, which does not necessarily imply sequentiality. In principle, firms that are able to face their obligations in the long term, that is, in a sustained manner, are considered solvent (Altman, 2000). On the contrary, they are understood as insolvent to entities on bankruptcy proceedings or declared bankrupt (Purnanandam, 2007). However, there are nuances between both extreme poles, which depend on the financial position. In case this is precarious, the organization goes through a period of stress; in the opposite scenario, it is concluded that it is healthy. In this line, according to that, top management will make decisions, mostly linked to two key indicators: (1) Profitability and (2) market share (Steinker et al., 2016).

In addition, knowledge of the probability of failure is not only useful for agents inside a firm but also useful for external stakeholders, who are gradually affected by the firm's activities. To this, every investor creditor of an aliquot could estimate the level of return he would expect for the acquisition of said assets, given the degree of risk assumed. Naturally, to the extent that financing reflects adverse possibilities in greater proportion, the expectations of return will be higher and vice versa (Sharpe, 1964). In addition, there are "insured" return investments, which have no risk of non-payment or reinvestment. In this regard, the difference between a return perceived as unequivocal and one with risk is called the Market Premium (Equity Premium).

In this context, Altman (2000) proposed a regressive model that manages to estimate the degree of solvency of a company, which he called Z-Score. It is widely disseminated and maintains a wide range of studies that corroborate its statistical significance (Jung \& Han, 2017; Legowik-Swiacik, 2017; Behera, 2016; Badea \& Matei, 2016; Lizarzaburu, 2014; Al-Kassar \& Soileau, 2014; Kumari, 2013; Hayes et al., 2010). For the time being, it was corroborated that $Z$ does not demonstrate validity in companies belonging to the financial system (Bannigidadmath \& Narayan, 2016). In addition, as far as it was possible to explore, most of the works are applied to entities located in economies of the first world, where the stock market is very developed, and there are no sampling limitations. The main problems detected in extrapolation to emerging 
economies are reduced trading volume, low asset liquidity, and sampling restrictions (Karolyi \& Wu, 2014), which means that, in spite of finding companies with adequate stock market ratios, the number of these would not necessarily be suitable to form a representative subset of the sector. Thus, as a contribution to the little related literature available, this study will seek to apply the Z-Score to seven Peruvian companies in the mining sector, using quarterly information in the period 2008-2018. The aim will be to demonstrate the significance of the impact of insolvency risk on the profitability of the shares of the sampled firms within the framework of a market performance model that includes Premium Equity. Additionally, in order to overcome information sufficiency obstacles, commonly related to the trading frequency of local market assets, only entities included in the s\&P/BVL Peru Select Index will be taken. Finally, it is expected to provide incentives to broaden the range of indicators used in asset performance analysis and to complement the interpretation of financial health.

\section{Theoretical Framework}

A company suffers financial stress when the generation of cash flows from the core business is insufficient to address the financial and commercial obligations that this demand (Behera, 2016). Empirically, Altman (2000) demonstrated that stress can be caused by four factors: profitability, working capital position, financial risk and liquidity, which he diluted and added in a formula, called Z-Score. The $\mathrm{Z}$ model is the distillation into a single measure of a series of deliberately chosen, weighted, and integrated financial ratios (Lizarzaburu, 2014). If the result derived from the $Z$ is within a certain defined range, the firm will be considered healthy, in need of optimization, or at potential failure (Hayes et al., 2010). In conclusion, the more the stress worsens, the greater the probability of collapse or insolvency. At present, the risk of insolvency has been corroborated as a statistically significant benchmark in the analysis of the performance of stock assets, typically equities (Hahn \& Yoon, 2016). Although the possibility of bankruptcy is not estimated with $\mathrm{Z}$ in all cases, there is a large literature that considers it highly accurate and consistent (Jung \& Han, 2017; Legowik-Swiacik, 2017; Badea \& Matei, 2016; Al-Kassar \& Soileau, 2014; Kumari, 2013). However, within the collected works, it is verified that the graduation of the impact of the level of financial stress in the performance of shares of Latin American firms has not been deep enough. Moreover, no econometric models 
were found to explain this effect and refer to the Peruvian market. The financial behavior of the entities and the commercial context has gone through significant changes since that time, causing a discordance in the real effect of each ratio reflected by the coefficients (Grice \& Ingram, 2001). Also, given that the regression was constructed from a sample of non-financial manufacturing companies from diverse productive sectors, the accuracy of the predictability of their results is pondered, as it is clear that each industry tends to report different levels of the same financial ratios (Smith \& Liou, 2007).

Similarly, barriers have been identified for the extrapolation of $\mathrm{Z}$ emerging economies. In the first place, since it has been estimated with us firms, its international applicability could not be expected due to differences related to the economic environment, legislation, culture, financial markets, and accounting practices (Ooghe \& Balcaen, 2007). Along these lines, Karolyi and Wu (2014) believe that the complexity of making stock market assessments for emerging economies falls under three central constraints: low trading volume, low trading frequency, and sampling restrictions. That is, even if liquid-emitting firms exist, the number of liquid-emitting firms is small enough not to be considered a representative subset of the population. In summary, it is argued that there are innate conceptual factors of $\mathrm{Z}$ that inhibit its ability to be extrapolated to other contexts because they affect the gap between healthy and insolvent companies (Ríos \& Pérez, 2013).

Altman et al. (2017) demonstrated an extremely solid significance for Z coefficients over time. However, they failed to disprove the formula's predisposition to the us market because by adding the country risk effect to the coefficients, better results were obtained. Likewise, this conclusion is repeated in the evaluation of productive sectors by incorporating the inherent risk of the item and the trend of the financial structure with which the projections are strengthened.

Despite this, strong evidence was obtained to corroborate the good performance of $\mathrm{Z}$ in an international context. Nevertheless, the possibility was reiterated of extracting more efficient models per country for the majority of European and non-European nations without ceasing to use the same ratios considered by Altman (2000). This would reasonably help the accuracy of the ranking and hence the predictability of financial instability (Xu \& Zhang, 2009). In this way, the statistical and conceptual validity for its application to emerging markets is corroborated. On the other hand, as of December 2014, the Lima 
Stock Exchange (BVL) entered into force with the s\&p Dow Jones for the calculation, licensing, marketing, and distribution of the s\&P/BVL indices, among them the Peru Select Index, denominated premium referent of the stock exchange for grouping the most relevant and liquid companies of the local market, which would address the limitations listed by Karolyi and Wu (2014). Finally, although the necessary information to modify the coefficients of the original model is not available, it is intended to continue with the position of $\mathrm{Xu}$ and Zhang (2009); the sample will be homogenized by compiling firms from the majority industry concerned in Peru Select: Mining. In this way, it is intended to cover the central conditioning factors that prevent a priori the conceptual support from the application in Peru.

In this context, information will be extracted from the following companies: Sociedad Minera Cerro Verde, Southern Copper Corporation, Compañía de Minas Buenaventura, Nexa Resources Peru (ex Compañía Minera Milpo), Minsur, Volcan Compañía Minera and Nexa Resources Atacocha (ex Compañía Minera Atacocha). Also, as a financial position estimator, Z-Score will be taken. This will be calculated on a quarterly basis from the available financial statements published by the stock market company (sMv). In this sense, a stock performance analysis based on market performance models will be proposed for each firm under a cross-sectional approach with 10-year data from the 2008-2018 period.

\section{Risk of Insolvency}

It is important to distinguish two key concepts: (1) Financial stress, and (2) insolvency. There are intermediate shades between solvency and bankruptcy through which a firm passes prior to the absolute imbalance. These statements are called financial stress and are defined as periods of low cash flow in which the entity incurs losses without bankruptcy (Purnanandam, 2007). Stress originates from factors internal and external to the organization. Internally, management errors, excessive leverage, mismanagement of production costs or even uncontrolled growth are considered. Externally, economic and political-legal factors are prioritized: unfavorable sectoral structure, government deregulatory activities, interest rate hike, increased level of competition and industrial overcapacity (Altman \& Hotchkiss, 2006). 
In this sense, Opler and Titman (1994) synthesize the consequences of financial stress in three central points. First, a financially stressed firm is susceptible to losing talented employees, invaluable suppliers, and customers, which results in a decline in market share vis-à-vis its healthier rivals. Second, the entity becomes voluble in transgressing its debt covenants and defaults on coupons or principal. This leads to increased "deadweight" losses, such as penalties for non-payment, accelerated debt repayment, and budget inflexibility. Third, the company would have to "let go" profitable investment projects, given the cost of external financing (Halteh et al., 2018).

To be specific, financial stress does not necessarily lead to corporate bankruptcy; however, in the event a firm transgresses the nuances of stress, it would be faced with insolvency (Habib et al., 2013). Since the evolution of the value of a firm's stock market assets is based on a stochastic process, the firm will find itself stressed whenever this value falls below a certain defined threshold throughout its life (Ferguson et al., 2011). In this state, the company will face commercial, financial, and investment disadvantages, which will make it prone to fail to demonstrate its true potential even when industry conditions improve. In short, it can be said that insolvency occurs when the value of the firm falls below the nominal value of its debt and, consequently, creditors gain control over it (Purnanandam, 2007).

\section{Model Z Altman}

Originally published by Altman in 1968, Z was constructed in order to integrate different classifications of financial ratios into a single index capable of predicting the risk of insolvency or bankruptcy susceptibility of a company. The model was based on data from 66 corporations during 1946-1965: 33 contained in Chapter X of the us National Bankruptcy Act and 33 of similar characteristics that remained in the market. The choice of financial indicators was made according to three categories: (1) Popularity within the literature, (2) Potential relevance for the study, and (3) Innovative form of some ratios in the analysis (Llizarzaburu, 2014). The purpose of its application is the evaluation of the financial health of an organization ${ }^{1}$ (Altman, 2000).

While Altman proposed an indicator that estimated the financial position of an organization, several publications consider $\mathbf{Z}$ directly as a benchmark for insolvency risk. This is not a mistake but an interpretative adjustment of the model to the research needs of each exponent. 
For Altman (1968), there were five factors whose combination effectively discriminated against those firms that had a potential probability of bankruptcy from those that did not. Likewise, the original sample is the same one used for the later modifications of the model; however, the information to be used was different from the projected field of application. While the model below was established for public firms, it was then adapted to fit private firms. ${ }^{2}$ The original $\mathrm{Z}$ is as follows:

$$
Z=0.012\left(X_{1}\right)+0.014\left(X_{2}\right)+0.033\left(X_{3}\right)+0.006\left(X_{4}\right)+0.999\left(X_{5}\right)
$$

The variables indicated correspond to the descriptions below:

a) $\mathrm{X}_{1}$ : Net Working Capital over Total Assets. It includes a liquidity indicator, showing which portion of the assets is used as a frequent investment for the development of the company's operations.

b) $\mathrm{X}_{2}$ : Retained earnings over total assets. It acts as a measure of accumulated profitability, presenting what portion of the value of the assets represents the reinvestment of the shareholders.

c) $\mathrm{X}_{3}$ : Earnings before Interest and Taxes on Total Assets. A measure of a company's productivity that manifests a more accurate result as an outcome of the core business, regardless of financial expenses, taxes, or leverage factors. It is seen as a measure of profitability.

d) $\mathrm{X}_{4}$ : Market Value of Equity over Book Value of Total Liabilities. It presents the financing structure of the company, considering how much the level of own resources employed represents against the resources of third parties. It should be noted that the company's own resources are quantified according to their commercial value for the market.

\footnotetext{
In Anglo-Saxon literature, public firms are those organizations that are open to the stock market, while private firms are those that are closed to the stock market. This differs from what is commonly understood in Perú, where a private entity only refers to a non-State organization but does not necessarily indicate whether it is closed or open. This paper will take as a public entity those organizations linked to the State and private those that are not.
} 
e) $\mathrm{X}_{5}$ : Sales Over Total Assets. It shows the efficiency of the company in the use of its assets to obtain income. Considered as a measure of profitability.

$\mathrm{Z}$ rates the results according to two benchmarks (Figure 1). If the result is below 1.80 (distress zone), it will be concluded that the company is susceptible. If, on the other hand, it is between 1.80 and 2.99 (grey zone), it will be considered at a probability of bankruptcy. Finally, if the indicator is greater than 2.99 (safe zone), the possibility of the firm continuing to operate will be high.

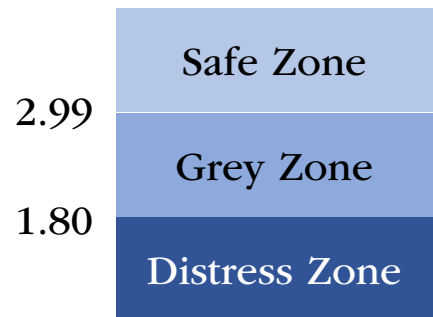

Figure 1. Estimated solvency level for public enterprises according to index $Z$ Source: Adapted from the design of Lizarzaburu (2014)

Although Altman's method (1968) was limited to public firms, the popularity of his equation, the rise of the empirical characterization of the insolvency risk, and the constant publication of criticisms and suggestions to his study encouraged the periodic diffusion of adjusted Zetas: (1) For public firms adjusted to the book value of the Patrimony and (2) For public firms or private industrial manufacturing or nonmanufacturing firms. The first adjustment is as follows:

$$
Z^{\prime}=0.717\left(X_{1}\right)+0.847\left(X_{2}\right)+3.107\left(X_{3}\right)+0.420\left(X_{4}\right)+0.998\left(X_{5}\right)
$$

In contrast to the original model, it has the advantage of being applicable to emerging markets. It also gives users the chance to extract the value of assets directly from the financial statements:
a) $\mathrm{X}_{1}$ : Net Working Capital over Total Assets
b) $\mathrm{X}_{2}$ : Retained earnings over total assets 
c) $\mathrm{X}_{3}$ : Earnings Before Interest and Taxes on Total Assets

d) $\mathrm{X}_{4}$ : Book Value of Equity over Total Liabilities. It presents the financing structure of the company, considering how much the level of own resources employed represents against the resources of third parties. It should be noted that the company's own resources are quantified according to their book value.

e) $\mathrm{X}_{5}$ : Sales over Total Assets.

$\mathrm{Z}$ rates the results according to two benchmarks (Figure 2). If the result is below 1.23 (distress zone), it will be concluded that the company is susceptible to bankruptcy. If it is between 1.23 and 2.90 (grey zone), it will be considered at a possibility of bankruptcy. Finally, if the indicator is greater than 2.90 (safe zone), the possibility of the firm continuing to operate will be high.

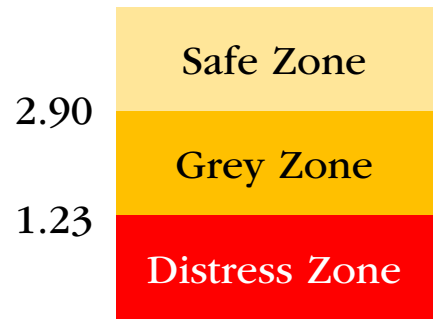

Figure 2. Estimated solvency level for private companies according to index $Z$ Source: Adapted from the design of Lizarzaburu (2014).

On the other hand, there is an adjustment to the original equation to estimate the risk of insolvency in those non-manufacturing companies in the industrial sector that, in turn, belong to emerging markets. This update was made with the objective that $\mathrm{Z}$ could be identified as a new global predictor index, independently of the segment of firms or their condition of public or private firm. The main advantage is its applicability to emerging economies.

$$
Z "=3.25+6.560\left(X_{1}\right)+3.260\left(X_{2}\right)+6.720\left(X_{3}\right)+1.050\left(X_{4}\right)
$$


In this variation, there is an independent term and four Xi variables, where the fifth is different from previous models:
a) $\mathrm{X}_{1}$ : Net Working Capital over Total Assets
b) $\mathrm{X}_{2}$ : Retained earnings over total assets
c) $\mathrm{X}_{3}$ : Earnings Before Interest and Taxes on Total Assets
d) $\mathrm{X}_{4}$ : Book Value of Equity over Total Liabilities

This model adjustment groups the results in a similar way to the two methods shown above (Figure 3). If the result is below 1.10 (distress zone), it will be concluded that the company is prone to go bankrupt. If, on the other hand, it is between 1.10 and 2.60 (grey zone), it will be considered at a probability of bankruptcy. Finally, if the indicator is greater than 2.60 (safe zone), the firm will be very likely to continue operating

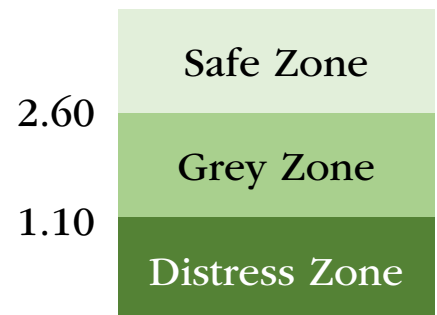

Figure 3. Estimated solvency level for companies in emerging markets according to $Z$ Source: Adapted from the design of Lizarzaburu (2014).

In that way, having described the difference between the Zs built by Altman (1998; 2000), it is necessary to mention that the present work will take the $Z$ ' for the development of a pilot test (Table 1). Although it was developed in the first instance as a response to problems in the valuation of private firms, it has a wide applicability to public firms and, above all, it has the empirical sufficiency of Altman et al. (2017) for use in emerging markets and open organizations, independently of their productive sector. 
Table 1. Topics to be developed regarding the risk of insolvency

\begin{tabular}{|c|c|c|}
\hline Variable & Section & Contents \\
\hline \multirow{3}{*}{ Insolvency Risk } & 1 & $\begin{array}{l}\text { Financial stress and insolvency: distinguishing } \\
\text { concepts, causes, and consequences. }\end{array}$ \\
\hline & 2 & $\begin{array}{l}\text { The Altman Z model: original regression, adap- } \\
\text { tations made, and application of each formula. }\end{array}$ \\
\hline & 3 & $\begin{array}{l}\text { Selection of the model to be used in the pilot } \\
\text { test: theoretical and empirical support. }\end{array}$ \\
\hline
\end{tabular}

Source: Own elaboration

\section{Return of Shares}

For Szymanska (2017), profitability can be understood as the extent of a positive financial result from the economic activity inherent to the business model; moreover, on a macroeconomic scale, it is the engine for the growth of an entire productive sector. On the other hand, Khan et al. (2017) consider that this represents the main objective established by senior management, which is particularly observed by their interest groups. Accordingly, it expresses the degree to which the capital invested generates added value for creditors. Finally, Polok et al. (2016), in the contemporary global context, turbulent and unpredictable as it is, encourage organizations to deepen their knowledge of factors that influence profitability in order to maintain their level of competitiveness in the market.

So, once a company chooses to carry out an Initial Public Offering (IPO), ${ }^{3}$ its ownership would be divided into titles that will eventually be offered in the primary market. In this sense, the price of these assets will derive from the perception of return and risk that investors possess. In this way, this situation segments the yield alternatives in profit for dividends and capital gains (Brealey et al., 2011). While the payment of dividends is related to the generation of accounting profit and corporate policies, the increase in share price is not entirely within the scope of the firm. For Karolyi and Wu (2014), this event will depend primarily on the individual performance of the company plus a contribution by the collective variation of all assets, in other words, the market, sectoral and economic level.

3 It represents the first time that a closed company chooses to "raise" capital by marketing a proportion of its shareholding from the stock market. 
At the individual level, Bodie et al. (2014) denote that the following areas are essential for measuring a firm's performance: (1) Level of leverage, (2) Efficiency in the use of assets, (3) Liquidity management, and (4) Return on investment. On the other hand, at the collective level, Obrimah et al. (2015) propose that the market is influenced by microeconomic variables that specifically affect the productive sector in question, as well as macroeconomic variables that alter asset prices throughout the economy. These can be political-legal, technological, social, environmental, or economic per se.

\section{Determinants of Return}

There are two approaches by which estimates of shareholder profitability may be proposed: (1) Longitudinal or time series, and (2) Transversal cut. As explained by Gow etal. (2010), the study of time series considers that the value of a variable is a product of past values of the same, called lags. In this case, the variable Xt would be explained by one or more $\mathrm{Xt}-\mathrm{k}$ lags, where $k$ indicates the number of periods prior to the moment $t$. On the other hand, from a cross-sectional perspective, the variable $(\mathrm{Xt})$ is manifested as a result of the movement of others ( $\mathrm{Yt}, \mathrm{Zt}$, etc.) in the same period.

Given a greater availability and diffusion of literature and empirical studies on the basis of cross-sectional regressions, in the present investigation, that perspective of analysis will be considered for the construction of the regression. In the specific case, a market yield model will be established, which, thanks to the inclusion of the Market Premium, can sincerely reflect the effect of the risk of insolvency on the yield of the share.

\section{Capital Model - CAPM}

Within the cross-sectional approach, the CAPM became such a popular method that, in current literature, it is considered a formula rather than a regressive model; that is, the presence of statistical error is ignored to facilitate its calculation and interpretation. Obrimah et al. (2015) indicate that the original or conventional model was proposed by Sharpe (1964) with the objective of explaining the expectations of profitability of an asset $\left(\mathrm{R}_{\mathrm{i}}\right.$ : Expected Return) from a linear equation of two elements: (1) The rate of the risk-free asset $\left(R_{\mathrm{f}}\right.$ : Risk-Free Rate) and (2) The Market Premium (Equity Risk Premium), which would be composed by the difference between the Return of the Market $\left(\mathrm{R}_{\mathrm{m}}\right.$ : Market Return) and 
the Risk-Free Rate. By the way the equation was presented, this construction scheme was popularized as a market performance model.

$$
R_{i}=R_{f}+(\beta)\left(R_{m}-R_{f}\right)+\varepsilon
$$

According to Harvey and Siddique (2000), the logic behind the development of Sharpe (1964) is to add a return premium for the additional risk assumed, which, in turn, is consistent with the correlation between the asset and market volatility $(\beta)$. Thus, in a first scenario, a risk-averse investor might opt for a safe return, such as that offered by Treasury Bonds, but to generate better performance in the same period of time, the same individual might decide to assume a risk premium. Under the conventional CAPM, the rate at which the expectation of return per marginal unit of risk increases will depend on the assigned Beta coefficient $(\beta)$. In Sharpe's (1964) opinion, the latter is a measure of volatility or systemic risk of a specific asset compared to that of a diversified portfolio (the market). This is calculated using statistical modeling and represents the evolutionary trend of a stock's fluctuation in response to market fluctuations. For Fernández (2019), the market risk premium is one of the most important but elusive parameters in finance. ${ }^{4}$ It is difficult to understand this term because it is commonly used to designate three different concepts: (1) Demanded (or Required) Market Premium, (2) Historical Market Premium, and (3) Expected Market Premium. The first is the incremental return of a diversified portfolio (the market) on a risk-free rate (treasury bonds) required by an investor. ${ }^{5}$ The second is the historical market spread on treasury bonds. The third is the expected spread of the market return on treasury bonds. Thus, there are authors who assume equivalence between these three concepts, despite being wrong.

Empirically, the САРм has represented more failures than relevance. Dalgin et al. (2012) tested it at the Istanbul Stock Exchange, covering monthly information from 1989 to 2008, during which the Turkish stock market experienced moments of high volatility as well as a relatively more stable ${ }^{6}$ environment. It used the variation between the closing prices

4 In Anglo-Saxon literature, the Market Premium is called Market Risk Premium, Equity Premium, or only Risk Premium, although they all refer to the same concept (Fernández, 2019).

5 This type of Market Premium is necessary for the calculation of the return required by the investment of own resources, normally treated as Cost of Equity.

6 This period is especially important because it contains high and low fluctuations in the Turkish economy, ranging from an inflation of $73 \%$, between 1988 and 2001, to an average of 17\%, post-2001. 
of the first and last round of the National 100 Index (Market Return) each month and the monthly interest rate of the bonds issued by the Central Bank of Turkey. In addition, based on the Fama-Macbeth assessment methodology (Fama \& Macbeth, 1973), they segmented the analysis periods according to their volatility. In the end, the results showed that neither the beta statistic nor the market performance explained the returns of the armed portfolios. In view of this, the authors take into account two possible reasons: (1) the noise in the data due to high volatility makes it almost impossible to detect any risk-return relationship in a cross-sectional regression, and (2) the CAPM lacks factors that better approximate the risk of the Istanbul Stock Exchange.

Similarly, Obrimah et al. (2015) the predictive capacity of the CAPM on the Nigerian Stock Exchange based on weekly data from a random $^{7}$ selection of 26 shares from different productive $^{8}$ sectors with relatively high trading frequencies in the course of 2006-2014. Finally, given the conventional specification of the САРМ, it was considered inappropriate for the evaluation of returns on the Nigerian Stock Exchange. However, it is necessary to mention that the exponents explicitly present which stock exchange index or risk-free rate they used for the estimation of the Market Premium, so a limitation is detected when not knowing under which criteria they were governed in the selection of both factors.

The study of Miralles-Quirós et al. (2017) obtained results in favor of the CAPM. These selected monthly data from 43 of the most liquid IBOvEsPa companies between 2000 and $2016^{9}$ from different industries. ${ }^{10}$ Along these lines, the Market Premium was estimated as the difference between the monthly variations of the mentioned index and the Special System for Settlement and Custody (SELIC) ${ }^{11}$ rate. In the end, the preliminary results indicated that the CAPM was valid for estimating the efficiency of the Brazilian market. In this way,

7 Despite the term "random," Obrimah et al. (2015) mention that the companies considered in the sampling pool were characterized as leaders in their respective industries. Therefore, they qualified their data collection style as "deliberate sampling."

8 The sectors concerned are as follows: Food products, household products, conglomerates, beverages, pharmaceuticals, petroleum products, construction and real estate, construction materials, and banking and financial services.

9 To avoid low trading frequencies, only those companies that were in the IBOVESPA index throughout the sampling horizon were considered. Thus, in case a company was included in the index for a period, but left and returned, it would not be taken into account in the test.

10 The sectors concerned are as follows: Basic materials, consumer goods, consumer services, financial services, industrial, oil and gas, technology, and government entities.

11 The Special System for Settlement and Custody (SELIC) is a monetary policy tool used by the Central Bank of Brazil for open market operations. 
based on the theoretical support and empirical evidence mentioned above, the statistical modeling of the return of shares of Peruvian companies will be considered based on a market performance model under a cross-sectional approach. The estimate of the Market Premium will be done with daily information of the s\&p/BvL Peru Select and the rate of the Sovereign Bonds in Suns to 10 years. Also, the selection of this reference of the BVL is given the containment of high frequency negotiation organizations, which, as already presented, is a common limitation in emerging markets. Thus, in line with Karolyi and Wu (2014), Altman's ${ }^{12} \mathrm{Z}$ will be taken as an individual performance measure, in such a way that not only the sphere of influence of the market is covered, but also the risk perception of each entity (Table 2).

Table 2. Topics to be developed with respect to Income from Shares

\begin{tabular}{|c|c|c|}
\hline Variable & Section & Contents \\
\hline \multirow{4}{*}{ Profitability of Shares } & 1 & Profitability: concept, performance alternatives, and influencing factors. \\
\hline & 2 & Determinants of cost-effectiveness: econometric modeling approaches. \\
\hline & 3 & The CAPM: purpose, elements, critiques, and empirical evidence. \\
\hline & 4 & $\begin{array}{l}\text { Selection of variables to consider in the econometric modeling of the return on } \\
\text { shares. }\end{array}$ \\
\hline
\end{tabular}

Source: Own elaboration

\section{Background to the Investigation}

The most current empirical reference is the study of Gao et al. (2018). They sought to explore the "anomaly of insolvency risk," which is based on the tendency of an action with high insolvency risk to obtain poor returns. To this end, the sample consisted of monthly information from 44930 companies in 38 countries over the period June 1992 to June 2013, totaling almost 4.3 million observations. The data collection covered the following regions: North America (the United States and Canada), developed European markets, Japan, developed Asia-Pacific markets (excluding Japan), and emerging ${ }^{13}$ markets. Observations

12 Quarterly Zetas will be calculated with the exception of the last quarter of 2018, whose financial statements have not yet been published.

13 The following markets were considered as emerging: Argentina, Brazil, Chile, China, India, Indonesia, Israel, Malaysia, Mexico, Pakistan, Philippines, Poland, South Africa, South Korea, Taiwan, Thailand, and Turkey. 
were obtained from secondary sources: the CRSP/Compustat North America database for us stocks, Compustat North America for Canadian stocks, Compustat Global for surplus region stocks, and MKмv for monthly observations of expected default frequencies (EDF). This way, ten portfolios were formed based on the EDF-risk ranking within each country and between countries, according to the EDF-risk decile for each month collected. ${ }^{14}$ In addition, the Market Premium was estimated as the difference between the overall index of the most representative stock exchange in each country and the us Treasury Bond rate, while Book-to-Market (B/M), Cash flow-to-Price (c/p), momentum, and sales volume ratios were used as individual performance measures. Finally, insolvency anomalies were demonstrated mostly in North American firms and European developed markets. In addition, evidence was found that risk-based fluctuations are explained by individual interpretations; for example, the return of stressed firms depends highly on single return (Saden \& Prihatiningtias, 2015).

Similarly, Hahn and Yoon (2016) looked to provide an empirical assessment of the determinants of stock performance under a cross-sectional approach applied to companies in Korea. For this purpose, the sample consisted of monthly information on shares listed on the Korean Stock Exchange during the period between May 1992 and April 2012, varying the number of organizations collected from 502 in 1992 to 624 in 2012. Observations were obtained from a secondary source: wisefn. So, nine portfolios were formed according to the sales volume of the firm as the first criterion and one of the other three ratios as the second criterion (в/M, E/P, or Share Rotation). In addition, the Market Premium was estimated as the difference between the KоspI index and the Monetary Stabilization Bond (мSв) rate, while the Equity Market Value, Book-to-Market (в/м), Earnings-to-Price (в/р), Share Rotation, and leverage ratios were used as benchmarks for individual performance. Finally, it was demonstrated that the best estimators of insolvency risk are sales volume and share rotation (higher insolvency risk, lower returns, on average). Additionally, it was found that there is a noise-induced bias in prices, which is substantial in the average returns of a portfolio with equal weights for each asset. The latter could totally change the statistical significance in the estimation of insolvency risk factors (Izan, 1984).

14 In the author's words, this methodology is country-neutral; that is, it ensures that the results do not capture differences in average returns in developed and emerging markets, for example. 
For their part, Garlappi and Yan (2011) sought to determine the effect of financial stress on the equity performance of non-financial us entities under a cross-sectional approach. For this purpose, the sample consisted of monthly information from more than 1.6 million companies during the period from February 1969 to November 2007. Observations were obtained from secondary sources: CRSP (Center for Research in Security Prices), мкмv (Moody's Kealhofer, McQuown, and Vasicek), and Compustat databases. Thus, ten portfolios were formed, according to the $\mathrm{s} / \mathrm{M}$ ratio and the probability of insolvency of each firm. In addition, for the calculation of the Market Premium, they used the general index of the NYSE, AMEX, and NASDAQ stock exchanges (as applicable), and the rate of the us Treasury Bonds, while the $\mathrm{B} / \mathrm{M}$, leverage, sales volume, and momentum ratios were used for the estimation of the insolvency risk. Finally, the following was concluded: (1) The presence of potential recovery after a stage of stress generates that the expected returns of its shares improve their average returns, and (2) The reduction of the default risk debilitates the perception of risk assumed by investors and rewards them with higher returns (less stress, more returns).

Finally, Chava and Purnanandam (2010) sought to contribute to the asset valuation literature by displaying three edges: (1) Significant changes in the risk-return balance depending on the share-return estimation approach, (2) The connection between default risk and share-return risk, and (3) The determinants of share-return. To this end, "the majority" 15 of open organizations that went bankrupt between 1963 and 2005, that had officialized insolvency documentation and that had been listed on AMEx (American Stock Exchange), NYSE (New York Stock Exchange), or NASDAQ, were sampled. Observations were obtained from secondary sources: CRSP and Compustat databases. In this way, ten portfolios were formed according to the EDF-risk of each company. In addition, they did not consider the Market Premium in their model but used the ratios of accounting profitability, leverage, sales volume, volatility of returns on shares, and past returns on shares to estimate the risk of insolvency. Thus, it was discovered that, contrary to most studies, as the risk of insolvency increased, market agents received a greater return on shares given the risk assumed (the greater the stress, the greater the returns, on average) for the post-1980 period until 2005. This is complemented by the fact that two additional anomalies occurred in the United

15 It is worth mentioning that the authors do not mention the number of sampled signatures or the total number of observations. 
States at the time: (1) There tended to be a valid basis for all ex-post research for ex-ante projections, and (2) The unusual number of companies declared bankrupt.

Table 3. Synthesis of empirical evidence and exponents considered

\begin{tabular}{|c|c|}
\hline Authors & Research Objective and Main Result \\
\hline \multirow[b]{2}{*}{ Gao et al. (2018) } & Explore the trend of high-risk insolvency stocks to perform poorly. \\
\hline & $\begin{array}{l}\text { There is a strong negative relationship between the risk of insolvency and the return } \\
\text { on shares in small-cap companies. }\end{array}$ \\
\hline \multirow{2}{*}{ Hahn \& Yoon (2016) } & $\begin{array}{l}\text { To provide an empirical assessment of the determinants of stock performance in } \\
\text { Korean companies. }\end{array}$ \\
\hline & $\begin{array}{l}\text { Market return, sales volume, and stock turnover are valid determinants for the stock } \\
\text { performance of Korean firms. }\end{array}$ \\
\hline \multirow{2}{*}{ Garlappi \& Yan (2011) } & $\begin{array}{l}\text { To study the consequences of a recovery after a stage of financial stress on stock } \\
\text { performance. }\end{array}$ \\
\hline & $\begin{array}{l}\text { Reducing the risk of insolvency leads to a reduction in the expected return on } \\
\text { shares. }\end{array}$ \\
\hline \multirow{2}{*}{ Chava \& Purnanandam (2010) } & To contribute valuation literature on the determinants of the return of an action. \\
\hline & In most cases, the risk of insolvency is negatively correlated with stock performance. \\
\hline
\end{tabular}

Source: Own elaboration

\section{Proposed Model}

In normal situations, a negative correlation of a company's degree of stress or risk of insolvency on the performance of its shares has been documented; that is, the greater the probability of a firm's bankruptcy is estimated, the variations in its share prices tend to fall, on average (Gao et al., 2017; Hahn \& Yoon, 2016; Garlappi \& Yan, 2011). This inverse association is generally attributed to the company's perception of individual performance (Steinker et al., 2016). In other words, improvements in working capital management, asset management, and financing structuring consolidate the entity's financial position, making it more prone to meeting its obligations. In addition, this should be reflected in its ratios of profitability, liquidity, leverage, and activity. In the opposite scenario, Chava and Purnanandam (2010) exposed a positive effect of insolvency risk on stock returns. However, they mentioned a limiting potential: there was a relatively large number of companies declared bankrupt during the selected analysis period and market. This becomes highly relevant when taking into account that, unlike the previous cases, the present exponents accepted having done their research in a "non-normal situation." Accordingly, it is worth highlighting the validity of momentum to explain returns (Garlappi \& Yan, 2011). That is, a tendency for declining 
assets to maintain such condition and, even more so in a period of stress, the risk premium demanded by investors would inevitably be raised to levels outside the issuing company's range of financial possibilities. Finally, in accordance with the synthesis presented and the information described in the literature review, the first research hypothesis is

H1: The risk of insolvency has a negative impact on the performance of the shares of Peruvian companies in the mining sector in the period 2008-2018.

Although the risk of insolvency has been corroborated as a fundamental determinant in the explanation of a share's performance, it is still volatile to argue under which indicators it should be estimated; how to measure how stressed a company is. In that sense, Altman's Z-Score aims to evaluate the state of an entity's financial position in such a way that it can be cataloged as healthy, in need of optimization, or at a potential failure (Hayes et al., 2010). This equation has been widely popularized and applied in both developed and emerging economies while being characterized as statistically effective (Jung \& Han, 2017; LegowikSwiacik, 2017; Behera, 2016; Badea \& Matei, 2016; Al-Kassar \& Soileau, 2014; Kumari, 2013; Hayes et al., 2010). Finally, landing the predictive capacity of the $\mathrm{Z}$ model to the Peruvian context, Lizarzaburu (2014) is, within what could be explored, the only author who conducted empirical tests based on firms listed in the BVL, obtaining an accuracy of $78 \%$ and cataloging it as "highly effective." Thus, the authors proposed:

H2: The Z-Score as an estimator of the insolvency risk, is statistically significant for the explanation of the returns on the shares of Peruvian companies in the mining sector between 2008 and 2018.

On the other hand, although the price of a share depends on the intrinsic factors of its issuer, it is also influenced by externalities beyond the control of the firm (Karolyi \& Wu, 2014; Ang et al., 2006). Economic growth, variations in the regulatory framework, and social elements can affect the operations of an entire productive sector both adversely and favorably (Obrimah et al., 2015). That is, the performance of a company is within the sphere of influence of the market where it operates (Sharpe, 1964). Along these lines, the CAPM, classified as a market yield model, seeks to explain the returns of an asset as a function of the excessive returns of the market over those of a risk-free asset, usually a collector of treasury bonds. The difference between these rates is known as the Market Premium. 
Although the CAPм has been branded as conventional for only including one factor, its construction has not been an obstacle to its statistical validity in all markets. In Brazil, Miralles-Quirós et al. (2017) obtained encouraging results applying it to the IBOVEsPA index. Likewise, although other authors discard their ability to predict the yields of an asset, they do not reject that the Market Premium is a key determinant in its modeling (Obrimah et al., 2015; Dalgin et al., 2012). Thus, the third hypothesis:

H3: The Market Premium has a positive impact on the share performance of Peruvian mining companies between 2008-2018.

Finally, the Market Premium will be measured by the difference between the return of the s\&p/BVL Peru Select index and the rate of Peruvian Sovereign Bonds in PEN. Figure 4 presents the graphical modeling of the variables included in this research with their respective estimators for the Peruvian market.

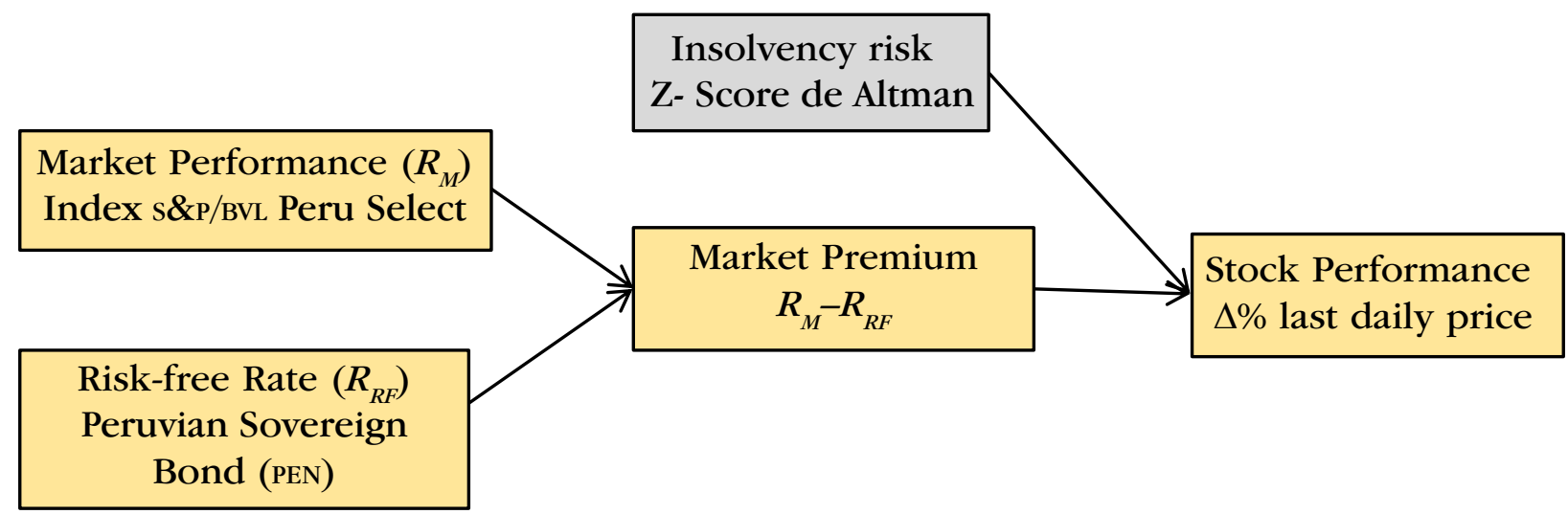

Figure 4. Graphical model of the third hypothesis

Source: Own elaboration

\section{Methodology}

For the present work, a non-experimental design will be used, since the aim is to determine the impact of the risk of insolvency on the performance of the shares without it involving the intentional manipulation of any of the proposed variables or sub-variables. Likewise, the type of design will be longitudinal since chronological and systematic data will be 
collected to be able to carry out a continuous evolutionary analysis of specific indices for each organization during a set period. Finally, the research will be explanatory in nature, given that it will seek to recognize the influence of one variable on the other. The selected companies will be Peruvians from the mining sector that, in turn, will be considered within the s\&P/BvL Peru Select Index between 2008 and 2018. ${ }^{16}$

Likewise, a non-probability sampling will be carried out due to the fact that each observation will be chosen according to the characteristics proposed by the researcher in a non-random way. In addition, the type of sampling to be used will be for convenience because the financial information necessary for the study is published by the smv and the BVL for free access and disposition. Also, the implicit reliability of this data is highlighted, given the audit requirement. The latter mitigates the risk of accounting manipulation, commonly known as cooking.

Table 4 shows the entities that make up the s\&p/BVL Peru Select Index as of December 31, 2017. However, only seven firms will be included for purposes of this study: (1) Compañía de Minas Buenaventura, (2) Nexa Resources Peru, (3) Sociedad Minera Cerro Verde, (4) Southern Copper Corporation, (5) Volcan Compañía Minera, (6) Minsur, and (7) Nexa Resources Atacocha.

Table 4. Constituent Organizations of the s\&p/BVL Peru Select Index

\begin{tabular}{llll}
\hline $\mathbf{N}^{\circ}$ & \multicolumn{1}{c}{ Issuing Company } & Mnemonic & $\begin{array}{c}\text { Stock Market } \\
\text { Sector }\end{array}$ \\
\hline 1 & Alicorp SAA & ALICORC1 & Consumption \\
\hline 2 & Cementos Pacasmayo SAA & CPACASC1 & Materials \\
\hline 3 & Compañía de Minas Buenaventura SAA & BVN & Materials \\
\hline 4 & Credicorp Ltd & BAP & Finance \\
\hline 5 & Ferreycorp SAA & FERREYC1 & Industrial \\
\hline 6 & Graña y Montero SAA & GRAM & Industrial \\
\hline 7 & InRetail Perú Corp. & INRETC1 & Consumption \\
\hline 8 & Intercorp Financial Services Inc. & IFS & Finance \\
\hline 9 & Compañía Minera Milpo SAA & MILPOC1 & Materials \\
\hline
\end{tabular}

16 It should be mentioned that the signatures selected for the sample did not have to be contained in the selective index since 2008. It is only necessary that as of December 31,2017, they had been considered in this index and those they have information from since 2008. Also, as described above, only the first, second, and third quarters of 2018 will be taken into account due to the lack of publication of the fourth quarter. 


\begin{tabular}{llll}
\hline $\mathbf{N}^{\circ}$ & \multicolumn{1}{c}{ Issuing Company } & Mnemonic & $\begin{array}{c}\text { Stock Market } \\
\text { Sector }\end{array}$ \\
\hline 10 & Sociedad Minera Cerro Verde SAA & CVERDEC1 & Materials \\
\hline 11 & Southern Copper Corporation & SCCO & Materials \\
\hline 12 & Trevali Mining Corporation & TV & Materials \\
\hline 13 & Unión Andina de Cementos SAA - & UNACEMC1 & Materials \\
\hline 14 & Volcan Compañía Minera SAA & VOLCABC1 & Materials \\
\hline 15 & BBVA Banco Continental & CONTINC1 & Finance \\
\hline 16 & Minsur SAA & MINSURI1 & Materials \\
\hline 17 & Refinería La Pampilla SA - Relapasa & RELAPAC1 & Energy \\
\hline 18 & Compañía Minera Atacocha SAA & ATACOBC1 & Materials
\end{tabular}

* Today, Company Minera Milpo is named after Nexa Resources Peru and trades under the mnemonic NEXAPEC1.

** Today, Company Minera Atacocha has the name Nexa Resources Atacocha and maintains its mnemonic. However, as of December 31,2018 , it is no longer included in the selective index.

Source: Prepared, based on data from the LSE.

The following are the reasons for the exclusion of the eleven additional firms (Table 5): (1) Due to the composition of the Financial Statements of вBva Banco Continental, Intercorp Financial Services, and Credicorp, it is not possible to apply model $\mathrm{Z}$ to these organizations, (2) Trevali Mining does not present published Financial Statements, and (3) Due to the money laundering investigation cases through which Graña and Montero transited, there is an external factor of high impact that adds a lot of volatility to the chronological evolution of the stock price. In this sense, due to the clear predominance of entities from the mining sector in the surplus range and the predisposition of $\mathrm{Z}$ to maintain homogeneous levels when applied to a certain item (Altman et al., 2017), the rest of the firms within the selective index (Alicorp, Ferreyros, Relapasa, Unacem, Cementos Pacasmayo, and InRetail Peru) were discarded.

Table 5. Companies sampled for the study

\begin{tabular}{llll}
\hline $\mathbf{N}^{\circ}$ & \multicolumn{1}{c}{ Issuing Company } & Mnemonic & Stock Market Sector \\
\hline 1 & Compañía de Minas Buenaventura SAA & BVN & Materials \\
\hline 2 & Compañía Minera Milpo SAA & MILPOC1 & Materials \\
\hline 3 & Sociedad Minera Cerro Verde SAA & CVERDEC1 & Materials \\
\hline 4 & Southern Copper Corporation & SCCO & Materials \\
\hline 5 & Volcan Compañía Minera SAA & VOLCABC1 & Materials \\
\hline 6 & Minsur SAA & MINSURI & Materials \\
\hline 7 & Compañía Minera Atacocha SAA & ATACOBC1 & Materials \\
\hline
\end{tabular}

Source: Prepared, based on data from the LSE. 
For the determination of the sample size, the following criteria shall be taken into account: (1) Companies that belong to the s\&P/BvL Peru Select Index, which is considered as a Premium reference of the BvL, (2) Those that belong to the financial system will be discriminated from the total, given the differentiation of the structuring of its accounting information would distort the analysis, (3) Those whose Financial Statements are published partially and discontinuously in the proposed evaluation period will be discriminated against, (4) Those who have taken part in events that condition their permanence in the market for reasons unrelated to their business performance will be discriminated against, for example, investigations on a possible case of money laundering, and (5) From the group obtained, the majority group belonging to the same productive sector or sectors as similar as possible will be taken, in such a way that the analysis is given in a standardized and equivalent manner for each firm.

Secondary data will be used as a data collection tool. As explained above, the smv requires any organization that chooses to obtain financing from the securities market to periodically present its audited financial statements in such a way as to be transparent to potential investors. This implies that the accounting information is already processed, validated, and audited, which facilitates the calculation of any indicator for the purposes of this study.

\section{Pilot Test}

In line with the methodology of the studies presented in the empirical background, the stages prior to the construction of the individual statistical model will be presented to explain the performance of the actions of each selected firm. For this purpose, the information will be processed, and the data will be interpreted according to a Normal distribution, given the Central Theorem of the Limit (Gao et al., 2017; Hahn \& Yoon, 2016; Garlappi \& Yan, 2011; Chava \& Purnanandam, 2010). Likewise, it is reiterated that the daily variations of the quotations of each company and of the market index were found, but the geometric average of the returns within the same quarter will be used as a representative figure (Dalginet al., 2012). 
Accordingly, mixed frequencies will not be treated in the construction of the model. Then, the return of shares being the independent variable, this will be explained through the state of the financial position, estimated with the Z', and the Market Premium, calculated as the difference between the market yield and the rate of the Sovereign Bonds in 10-year PEN. Likewise, due to CVERDEC1, scCO, and BVN being quoted in dollars, their value in PEN was estimated as the product of their quotation and the bank exchange rate of the same day's sale prior to the calculation of daily yields obtained from the sBs. In this way, the analysis of yields in the same currency was standardized.

On the other hand, a 95\% confidence level ( $\alpha=5 \%)$ was considered as it is the most common within the literature in homogeneous evaluations (Gao et al., 2017; Hahn \& Yoon, 2016; Garlappi \& Yan, 2011; Chava \& Purnanandam, 2010). Thus, the decision criterion for the evaluation of the significance of a variable within the regression will be the presence of a P-value less than alpha (if $\mathrm{p}$-value $<\alpha$, the variable is significant to explain the performance of the actions and vice versa), which would imply the rejection of the null hypothesis (H0: the model or the variable is not significant).

Finally, the results analysis scheme will follow the following order: (1) Presentation and interpretation of the Pearson linear correlation coefficients, (2) Presentation of the constructed regression, (3) Interpretation of the individual and global tests, and (4) Presentation of the determination coefficients $\left(\mathrm{R}^{2}\right)$ and standard deviation of the residues. Additionally, in case one of the variables is not significant, the regression established without them will be considered in the annexes.

\section{Pilot test results}

Following the scheme set out below, the correlation matrix of the variables considered is presented (Table 6). 
Table 6. Pearson's correlation matrix between Zetas, Stocks and Market Premium

\begin{tabular}{|c|c|c|c|c|c|c|c|c|c|c|c|c|c|c|c|}
\hline & $\mathrm{Z}_{\mathrm{CVE}}$ & $\mathrm{Z}_{\mathrm{scc}}$ & $Z_{\text {BVN }}$ & $Z_{\mathrm{NEX}}$ & $\mathrm{Z}_{\mathrm{MIN}}$ & $\mathrm{z}_{\mathrm{vOL}}$ & $Z_{\text {ATA }}$ & CVE & $\mathrm{scc}$ & BVN & NEX & MIN & VOL & ATA & MPR \\
\hline$Z_{\text {CVE }}$ & 1.00 & & & & & & & & & & & & & & \\
\hline$Z_{\mathrm{scc}}$ & 0.36 & 1.00 & & & & & & & & & & & & & \\
\hline$Z_{\text {BVN }}$ & 0.40 & 0.54 & 1.00 & & & & & & & & & & & & \\
\hline $\mathbf{Z}_{\text {NEX }}$ & 0.40 & 0.05 & -0.03 & 1.00 & & & & & & & & & & & \\
\hline$Z_{\text {MIN }}$ & 0.58 & -0.29 & 0.01 & 0.39 & 1.00 & & & & & & & & & & \\
\hline $\mathrm{Z}_{\mathrm{vOL}}$ & 0.74 & 0.01 & 0.17 & 0.69 & 0.80 & 1.00 & & & & & & & & & \\
\hline$Z_{\text {ATA }}$ & 0.05 & -0.17 & -0.12 & 0.51 & 0.13 & 0.26 & 1.00 & & & & & & & & \\
\hline CVE & 0.13 & -0.27 & 0.02 & 0.11 & 0.33 & 0.21 & 0.02 & 1.00 & & & & & & & \\
\hline SCC & 0.26 & -0.19 & -0.04 & 0.09 & 0.31 & 0.28 & 0.02 & 0.48 & 1.00 & & & & & & \\
\hline BVN & -0.28 & -0.22 & -0.16 & -0.18 & -0.08 & -0.16 & -0.28 & 0.23 & 0.23 & 1.00 & & & & & \\
\hline NEX & -0.13 & 0.07 & 0.01 & -0.15 & -0.17 & -0.16 & -0.04 & 0.07 & 0.05 & 0.13 & 1.00 & & & & \\
\hline MIN & -0.20 & -0.19 & -0.10 & -0.17 & -0.08 & -0.14 & -0.27 & 0.31 & 0.10 & 0.85 & 0.22 & 1.00 & & & \\
\hline VOL & -0.22 & -0.17 & -0.11 & -0.20 & -0.09 & -0.16 & -0.29 & 0.25 & 0.04 & 0.84 & 0.19 & 0.99 & 1.00 & & \\
\hline ATA & -0.22 & -0.06 & -0.06 & -0.25 & -0.19 & -0.22 & -0.19 & 0.20 & 0.02 & 0.70 & 0.52 & 0.86 & 0.85 & 1.00 & \\
\hline MPR & 0.05 & -0.31 & -0.03 & -0.08 & 0.20 & 0.07 & -0.07 & 0.61 & 0.60 & 0.52 & 0.23 & 0.46 & 0.37 & 0.38 & 1.00 \\
\hline
\end{tabular}

Source: Prepared, based on information from SMV and Bloomberg.

According to the correlation matrix (Table 6), a priori, it can be observed that the yields of CVERDEC1 and SCCO are the most sensitive to variations in the Market Premium; for example, an increase of one percentage point in the market quotation above the rate offered by 10 -year PEN sovereign bonds would generate a $60 \%$ increase in the quotation of scco. It should also be noted that all the shares presented a direct link with the Prima de Mercado, which gives a first indication of a positive impact of this variable against the proposed yields. On the other hand, with the exception of CVERDEC1, the rest of the shares presented an inverse correlation with the financial position (Z-Score), being scCo and АТАСОВс1 the most sensitive to this; for example, an increase of scCo's Z' by one percentage point would decrease its price by $19 \%$. This is in line with what Chava and Purnanandam (2010) achieved at an efficiency level of $85 \%$ (six out of seven firms). However, no more meticulous analysis can be made with such data.

On the other hand, Table 7 presents the regression statistics for each firm, as well as the P-value of global and individual tests. The group of columns Statistics (Es) comprises the determination coefficient $\left(R^{2}\right)$, the standard deviation of the regression residues $(\sigma)$, 
and the number of observations considered (N). The group of columns Global Test (PG) summarizes the analysis of variance of the model and includes the critical value of the test (F) and its respective P-value. Finally, the group of columns Individual Tests (PI) shows the estimated coefficients for each independent variable, the standard error of these (SE), the critical value of the tests $(T)$, and their respective p-value.

Table 7. Statistical Models: Explanation of Stock Performance

\begin{tabular}{|c|c|c|c|c|c|c|c|c|c|c|}
\hline & & \multirow[b]{2}{*}{$\mathbf{R}^{2}$} & \multicolumn{2}{|c|}{ Statistics (ES) } & \multicolumn{2}{|c|}{ Global Test (PG) } & \multicolumn{3}{|c|}{ Individual Tests (PI) } & \multirow[b]{2}{*}{$p$ value } \\
\hline & & & $\sigma$ & $\mathbf{N}$ & $F$ & Valor P & Coeficients & SE & $\mathbf{T}$ & \\
\hline \multirow{4}{*}{ CVE } & CVERDEC 1 & 0.387 & 3.320 & 43 & 12.645 & 0.000 & & & & \\
\hline & Intercept & & & & & & -0.459 & 1.360 & -0.337 & 0.738 \\
\hline & $Z_{C V E}$ & & & & & & 0.334 & 0.430 & 0.777 & 0.441 \\
\hline & MPR & & & & & & 3.017 & 0.613 & 4.925 & 0.000 \\
\hline \multirow{4}{*}{ SCC } & scco & 0.365 & 1.649 & 43 & 11.480 & 0.000 & & & & \\
\hline & Intercept & & & & & & 0.291 & 1.145 & 0.254 & 0.801 \\
\hline & $\mathrm{Z}_{\mathrm{scC}}$ & & & & & & -0.002 & 0.241 & -0.008 & 0.994 \\
\hline & MPR & & & & & & 1.455 & 0.319 & 4.555 & 0.000 \\
\hline \multirow{4}{*}{ BVN } & BVN & 0.291 & 4.146 & 43 & 8.222 & 0.001 & & & & \\
\hline & Intercept & & & & & & 2.139 & 1.635 & 1.309 & 0.198 \\
\hline & $Z_{\text {BVN }}$ & & & & & & -0.409 & 0.375 & -1.092 & 0.281 \\
\hline & MPR & & & & & & 2.958 & 0.765 & 3.869 & 0.000 \\
\hline \multirow{4}{*}{ NEX } & nexapec1 & 0.071 & 2.316 & 43 & 1.528 & 0.229 & & & & \\
\hline & Intercept & & & & & & 1.713 & 1.140 & 1.503 & 0.141 \\
\hline & $Z_{\text {NEX }}$ & & & & & & -0.549 & 0.611 & -0.898 & 0.375 \\
\hline & MPR & & & & & & 0.611 & 0.428 & 1.427 & 0.161 \\
\hline \multirow{4}{*}{ MIN } & MINSURI1 & 0.239 & 7.435 & 43 & 6.267 & 0.004 & & & & \\
\hline & Intercept & & & & & & 2.647 & 2.005 & 1.320 & 0.194 \\
\hline & $Z_{\text {MIN }}$ & & & & & & -0.518 & 0.408 & -1.268 & 0.212 \\
\hline & MPR & & & & & & 4.887 & 1.399 & 3.493 & 0.001 \\
\hline \multirow{4}{*}{ VOL } & VOLCABC1 & 0.174 & 46.296 & 43 & 4.226 & 0.022 & & & & \\
\hline & Intercept & & & & & & 25.841 & 18.310 & 1.411 & 0.166 \\
\hline & $\mathrm{Z}_{\mathrm{VOL}}$ & & & & & & -19.950 & 15.217 & -1.311 & 0.197 \\
\hline & MPR & & & & & & 22.957 & 8.556 & 2.683 & 0.011 \\
\hline \multirow{4}{*}{ ATA } & ATACOBC1 & 0.169 & 16.696 & 43 & 4.067 & 0.025 & & & & \\
\hline & Intercept & & & & & & 4.602 & 3.091 & 1.489 & 0.144 \\
\hline & $Z_{\text {ATA }}$ & & & & & & -5.236 & 4.677 & -1.119 & 0.270 \\
\hline & MPR & & & & & & 7.840 & 3.085 & 2.542 & 0.015 \\
\hline
\end{tabular}

Source: Prepared, based on information from SMV and Bloomberg 
Thus, in general, it is observed that the inclusion of the statement of financial position referred to through the $Z^{\prime}$ of Altman ( $\left.\mathrm{Zi}\right)$ is not valid for any company; that is, the null hypothesis $\left({ }^{\mathrm{P}}\right.$-value $\left.>\alpha\right)$ is not rejected. On the contrary, with the exception of Nexa Resources Peru, the Market Premium (MPR) is significant in $85 \%$ of the entities. Additionally, with the exception of Nexa Resources Peru, the rest of the models pass the global test, rejecting the null hypothesis ( $\mathrm{p}$-value $<\alpha)$.

In this line, the best determination coefficients $\left(R^{2}\right)$ are appreciated for CVERDEC1 and SCCO, being $38.7 \%$ and $36.5 \%$, respectively. This indicates that, in the case of CVERDEC1, the regression explains $38.7 \%$ of the variability of the data. Likewise, at the bottom of the ranking, R2 only reaches $7.1 \%$. On the other hand, NEXAPEC1 and SCCO present the lowest standard deviations for residues (2.31 and 1.64, in that order), although there is a wide difference between determination coefficients. On the other hand, vOLCAвC1 and ATACOBC1 differences are farther from their real return: 46.3 and 16.7 , respectively.

\section{Conclusions}

The objective of this study is to assess the importance of bad debt risk in explaining the historical performance of stocks through a market performance model with a cross-sectional approach. Quarterly data from a sample of 7 Peruvian mining companies belonging to the s\&P /BVL Peru Select Index were analyzed during the 2008-2018 period, covering 43 observations per company. In addition, given the wide acceptance of the Altman Z-Score model for the evaluation of the financial situation, it was considered that it was used to infer financial stress (Jung \& Han, 2017; Legowik-Swiacik, 2017; Behera, 2016; Badea \& Matei, 2016; Lizarzaburu, 2014; Al-Kassar \& Soileau, 2014; Kumari, 2013; Hayes et al., 2010). In addition, the market premium was taken into account, since the shares are within the market's area of influence (Sharpe, 1994).

Despite the important range of studies mentioned above, no statistical significance of Altman's Z-Score as an estimator of insolvency risk could be found in the explanation of stock returns, in any case. That is, the second hypothesis is rejected. Although Altman et al. (2017) 
found the index valid for Colombia, this could not necessarily be analogous in Peru; as Gao et al. (2018) state, there is high volatility in the results between countries when it comes to methodologies applied to emerging markets. In addition, it should be emphasized that the preliminary results are based on a sample of mining only firms; therefore, the same conclusion could not be extrapolated a priori to other industries and, much less, to other countries.

In that sense, with respect to the Market Premium, according to the results of MirallesQuirós et al. (2017), Obrimah et al. (2015), and Dalgin et al. (2012), there is sufficient statistical evidence to confirm that the Market Premium is a significant variable in the performance analysis of a share and has a positive impact; in other words, the third hypothesis is not rejected. Except in the case of Nexa Resources Peru, which did not reject the null hypothesis in the global or individual test, all models considered the impact of the Market Premium on the performance of the assets relevant and direct. Also, according to the models, considering only the Market Premium in annex 2, the significance of it is maintained, which suggests, like Miralles-Quirós et al. (2017) in Brazil, the conventional CAPM valid and effective for the Peruvian mining sector.

In this manner, contrary to what was predicted by Gao et al. (2018), Hahn and Yoon (2016), Garlappi and Yan (2011), and Chava and Purnanandam (2010), given the preliminary results obtained, there is sufficient statistical evidence to affirm that the risk of insolvency is not significant in the explanation of the performance of shares of Peruvian mining companies contained in the s\&P/BVL Peru Select Index during 2008-2018; that is, the first hypothesis is rejected. However, it is emphasized that, within the review, no study presented an econometric model with the Z-Score as an estimate of the risk of insolvency in emerging markets; therefore, this could not necessarily be distinguished as the most representative reference. It is also stressed that the study of emerging markets is important, not despite its emerging nature but precisely because of it (Dalgin et al., 2012).

Finally, it should be reiterated that Altman's Z' used in the present investigation is not the only indicator of the risk of insolvency found in the literature. In addition, it is recognized as a limitation the fact that this only captures the effect of the accumulated sales of a quarter due to the fact that, because of the nature of the financial statements, the statement of financial situation drags the balances of past periods, but the statement of results does not. That is to say, distortions are generated in the projection of the company's financial 
health status, as it does not reflect the correct risk, especially in the ROA and sales rotation. Finally, it is worth noting that the risk of insolvency could maintain different results if estimated by variables other than Z' and, in turn, other Peruvian industries.

\section{References}

Al-Kassar, T. A., \& Soileau, J. S. (2014). Financial performance evaluation and bankruptcy prediction (failure)1. Arab Economic and Business Journal, 9(2), 147-155. https://doi. org/10.1016/j.aebj.2014.05.010

Altman, E. (1968). Financial ratios, discriminant analysis and the prediction of corporate bankruptcy.Journal of Finance, 23(4), 589-609. https://www.jstor.org/stable/2978933?se$\mathrm{q}=1$ \# page_scan_tab_contents

Altman, E. (2000). Predicting financial distress of companies: revisiting the Z-Score and ZETA models. http://pages.stern.nyu.edu/ ealtman/Zscores.pdf

Altman, E., \& Hotchkiss, E. (2006). Corporate finance distress and bankruptcy: Predict and avoid bankruptcy, analyze and invest in distressed debt. John Wiley \& Sons.

Altman, E. I., Iwanicz-Drozdowska, M., Laitinen, E. K., \& Suvas, A. (2017). Financial distress prediction in an international context: A review and empirical analysis of Altman's Z-score model. Journal of International Financial Management \& Accounting, 28(2), 131-171. https://doi.org/10.1111/jifm.12053

Ang, A., Hodrick, R. J., Xing Y., \& Zhang, X. (2006). The Cross-section of Volatility and Expected Returns. Journal of Finance, 61(1), 259-99. https://doi.org/10.1111/j.15406261.2006.00836.x

Badea, I-R., \& Matei, G. (2016). The Z-score model for predicting periods of financial instability. Z-score estimation for the banks listed on bucharest stock exchange. Finanţe: Provocările Viitorului, 16(18), 24-35. http://financejournal.ro/fisiere/revista/634869503018-003.pdf

Bannigidadmath, D., \& Narayan, P. K. (2016). Stock return predictability and determinants of predictability and profits. Emerging Markets Review, 26, 153-173. https://doi.org/10.1016/j. ememar.2015.12.003

Behera, P. (2016). Bankruptcy prediction by using the Altman Z-score model in Oman. Australasian Accounting Business and Finance Journal, 10(4), 70-80. https://doi. org/10.14453/aabfj.v10i4.6

Brealey, R., Myers, S., \& Allen, F. (2011). Principles of corporate finance. McGraw-Hill/Irwin. 
Bodie, Z., Kane, A., \& Marcus, A. (2014). Investments. McGraw-Hill Education.

Chava, S., \& Purnanandam, A. (2010). Is default risk negatively related to stock returns? Review of Financial Studies, 23(6), 2523-2559. http://econpapers.repec.org/article/ouprfinst/v 3a23_3ay_3a2010_3ai_3a6_3ap_3a2523-2559.htm

Dalgin, M. H., Gupta, K., \& Sraiheen, A. (2012). Testing сарм for the Istanbul stock exchange. International Journal of Economic Perspectives, 6(3), 224-234.

Fama, E. F., \& MacBeth, J. D. (1973). Risk, return, and equilibrium: Empirical tests. Journal of Political Economy, 81(3), 607-636. http://www.jstor.org.esan.idm.oclc.org/stable/1831028

Ferguson, A., Clinch, G., \& Kean, S. (2011). Predicting the failure of developmental gold mining projects. Australian Accounting Review, 21(1), 44-53. https://EconPapers.repec.org/ RePEc:bla:ausact:v:21:y:2011:i:1:p:44-53

Fernández, P. (2019). WACC and CAPM according to utilities regulators: Confusions, errors and inconsistencies. http://dx.doi.org/10.2139/ssrn.3327206

Gao, P., Parsons, C. A., \& Shen, J. (2018). Global relation between financial distress and equity returns. Review of Financial Studies, 31(1), 239-277. https://doi.org/10.1093/rfs/hhx060

Garlappi, L., \& Yan, H. (2011). Financial distress and the cross-section of equity returns. The Journal of Finance, 66(3), 789-822. https://doi.org/10.1111/j.1540-6261.2011.01652.x

Gow, I. D., Ormazabal, G., \& Taylor, D. J. (2010). Correcting for cross-sectional and time-series dependence in accounting research. The Accounting Review, 85(2), 483-512. https:// www.jstor.org/stable/20744139

Grice, J., \& Ingram, R. (2001). Tests of the Generalizability of Altman's Bankruptcy Prediction Model. Journal of Business Research, 54, 53-61. https://doi.org/10.1016/S01482963(00)00126-0

Habib, A., Bhuiyan, M. B. U., \& Islam, A. (2013). Financial distress, earnings management and market pricing of accruals during the global financial crisis. Managerial Finance, 39(2), 155-180. http://www.econis.eu/PPNSET?PPN=742528693

Halteh, K., Kumar, K., \& Gepp, A. (2018). Using cutting-edge tree-based stochastic models to predict credit risk. Risks, 6(2), 55. https://doi.org/10.3390/risks6020055

Hahn, J., \& Yoon, H. (2016). Determinants of the cross-sectional stock returns in Korea: Evaluating recent empirical evidence. Pacific-Basin Finance Journal, 38, 88-106. https:// doi.org/10.1016/j.pacfin.2016.03.006

Harvey, C. R., \& Siddique, A. (2000). Conditional skewness in asset pricing tests. Journal of Finance, 55, 1263-1295. https://doi.org/10.1111/0022-1082.00247 
Hayes, S., Hodge, K., \& Hughes, L. (2010). A study of the efficacy of Altman's Z to predict bankruptcy of specialty retail firms doing business in contemporary times. Economics E Business Journal: Inquiries \& Perspectives, 3(1), 122-134. https://nebeconandbus.org/ journal/EBJI2010HayesHodgeHughes.pdf

Izan, H. Y. (1984). Corporate distress in Australia. Journal of Banking \& Finance, 8(2), 303320. https://doi.org/10.1016/0378-4266(84)90010-4

Jung, H., \& Han, Y. (2017). Default risk and firm value of shipping \& logistics firms in Korea. The Asian Journal of Shipping and Logistics, 33(2), 61-65. https://doi.org/10.1016/j. ajs1.2017.06.003

Karolyi, G. A., \& Wu, Y. (2014). Size, value, and momentum in international stock returns: $A$ new partial-segmentation approach. http://w4.stern.nyu.edu/finance/docs/pdfs/Seminars/ Karolyi_Wu_Size_Value_and_Momentum_in_International_Stock_Returns_01102014.pdf

Khan, K. I., Qadeer, F., \& Ghafoor, M. M. (2017). Debt specialization within profitability subgroups: A new perspective of debt structure choices. FWU Journal of Social Sciences, 11(2), 92-108. https://ssrn.com/abstract=3110899

Kumari, N. (2013). Evaluation of financial health of ммтс of india: A Z-score model. European Journal of Accounting and Auditing E Financial Research, 1(1), 36-43. https://www. eajournals.org/wp-content/uploads/EVALUATION-OF-FINANCIAL-HEALTH-OF-MMTCOF-INDIA.pdf

Legowik-Swiacik, S. (2017). The application of the Altman Z-score in the assessment of the business model of the company. Research Papers of the Wroclaw University of Economics, (474), 85-94. https://www.dbc.wroc.pl/dlibra/publication/41369/edition/37304/content

Lizarzaburu, E. (2014). Análisis del modelo Z de altman en el mercado peruano. Universidad E Empresa, 16(26), 141-158. https://doi.org/10.12804/rev.univ.empresa.26.2014.05

Miralles-Quirós, M., Miralles-Quirós, J. L., \& Goncalves, L. M. V. (2017). Testing the efficienсу-САРм joint hypothesis in the вOVESPA. Revista de Gestao, Financas e Contabilidade, 7(3), 414-435.

Obrimah, O. A., Alabi, J., \& Ugo-Harry, B. (2015). How relevant is the capital asset pricing model (САPM) for tests of market efficiency on the Nigerian stock exchange? African Development Review, 27(3), 262-273. https://doi.org/10.1111/1467-8268.12145

Ooghe, H., \& Balcaen, S. (2007). Are failure prediction models widely usable? An empirical study using a Belgian dataset. Multinational Finance Journal, 11, 33-76. https://ssrn. com/abstract $=2623512$

Opler, T., Titman, S. (1994). Financial distress and corporate performance. Journal of Finance, 49(3), 1015-1040. https://doi.org/10.1111/j.1540-6261.1994.tb00086.x 
Polok, D., Michalski, P., Szewczyk, D., Keil, D., Wieczore, S., Kaciakova, P., Incze, Z., Rycerz, J., Nisztuk, T., Dvouletý, O., \& Krzemiński, P. (2016). Future of the Visegrad Group. https:// doi.org/10.13140/RG.2.1.3942.7444

Purnanandam, A. (2007). Financial distress and corporate risk management: Theory and evidence. https://doi.org/10.1016/j.jfineco.2007.04.003

Ríos, C. E. C., \& Pérez, J. E. A. (2013). Análisis financiero integral de empresas colombianas 2009-2010: perspectivas de competitividad regional. Entramado, 9(1), 84-100.

Saden, N. S., \& Prihatiningtias, Y. W. (2015). Financial distress prediction of mining companies listed in Indonesian Stock Exchange: An analysis using Altman Z-score model.Jurnal Ilmiah Mahasiswa FEB, 4(1). https://jimfeb.ub.ac.id/index.php/jimfeb/article/view/2411

Sharpe, W. F. (1964). Capital asset prices: A theory of market equilibrium under conditions of risk. Journal of Finance, 19, 425-442. https://doi.org/10.2307/2977928

Smith, M., \& Liou, D. (2007). Industrial Sector and Financial Distress. Managerial AuditingJournal, 22, 376-391. https://www.emeraldinsight.com/doi/pdfplus/10.1108/02686900710741937

Steinker, S., Pesch, M., \& Hoberg, K. (2016). Inventory management under financial distress: An empirical_analysis. International Journal of Production Research, 54(17), 5182-5207. https://doi.org/10.1080/00207543.2016.1157273

Szymanska, E. J. (2017). Determinants of profitability of enterprises of meat industry in Poland. Acta Scientiarum Polonorum. Oeconomia, 16(3), 83-91. https://doi.org/10.22630/ ASPE.2017.16.3.36

Xu, M., Zhang, C. (2009). Bankruptcy prediction: The case of Japanese listed companies and application in credit rating for listing firms in China. Review of Accounting Studies, 14, 534-558. https://doi.org/10.1007/s11142-008-9080-5 